\title{
Efek stress terhadap penyembuhan luka dibetik di klinik IWCC majene
}

\author{
Junaedi Yunding ${ }^{1}$, Ibrahim ${ }^{1}$ \\ ${ }^{1}$ Stikes Marendeng Majene
}

Keywords :

Diabetes Mellitus, Stres, Ulkus

Diabetik.

\section{Kontak :}

Junaedi Yunding

Email : yundingj05@gmail.com

Stikes Marendeng Majene

Vol 1 No 1 September 2018

DOI:

https://doi.org/10.31605/jhealt.v2i1

(C)2018J-Healt

ini adalah artikel dengan akses terbuka dibawah licenci CC BY-NC-4.0

https://creativecommons.org/licenses/by-nc/4.0/

\begin{abstract}
Abstrak
Diabetes melitus merupakan suatu kondisi kronis yang terjadi ketika pankreas tidak dapat menghasilkan insulin dalam jumlah cukup atau ketika tubuh tidak dapat menggunakan insulin yang dihasilkan secara efektif. salah satu komplikasi pada pasien diabetes adalah neuropati pada ekstremitas bawah yang menyebabkan ulkus diabetik. Pada penderita yang mengalami luka, akan lebih lama sembuh pada pasien yang mengalami stres karena dapat meningkatkan level beberapa hormon dalam darah, yaitu kortisol, aldosteron, dan epinefrin. Penelitian ini bertujuan untuk Mengidentifikasi hubungan stres dengan penyembuhan luka diabetik pada pasien diabetes melitus. Penelitian ini menggunakan observasional analitik denngan desain penelitian kohort prospektif. Jumlah sampel yang digunakan sebanyak 30 pasien yang mengalami luka ulkus diabetik. Pengumpulan data dilakukan dengan tehnik observasi dan menggunakan kuesioner DASS-42. Analisis yang digunakan yaitu menggunakan uji Chi Square. Hasil penelitian didapatkan bahwa mayoritas responden mengalami stres sedang yaitu sebanyak $70 \%$. Kesimpulan didapatkan bahwa terdapat hubungan antara stres dengan proses penyembuhan luka ulkus diabetik.
\end{abstract}

Abstract
Diabetes melitus merupakan suatu kondisi kronis yang terjadi ketika
pankreas tidak dapat menghasilkan insulin dalam jumlah cukup atau
ketika tubuh tidak dapat menggunakan insulin yang dihasilkan secara
efektif. salah satu komplikasi pada pasien diabetes adalah neuropati
pada ekstremitas bawah yang menyebabkan ulkus diabetik. Pada
penderita yang mengalami luka, akan lebih lama sembuh pada pasien
yang mengalami stres karena dapat meningkatkan level beberapa
hormon dalam darah, yaitu kortisol, aldosteron, dan epinefrin.
Penelitian ini bertujuan untuk Mengidentifikasi hubungan stres dengan
penyembuhan luka diabetik pada pasien diabetes melitus. Penelitian ini
menggunakan observasional analitik denngan desain penelitian kohort
prospektif. Jumlah sampel yang digunakan sebanyak 30 pasien yang
mengalami luka ulkus diabetik. Pengumpulan data dilakukan dengan
tehnik observasi dan menggunakan kuesioner DASS-42. Analisis yang
digunakan yaitu menggunakan uji Chi Square. Hasil penelitian
didapatkan bahwa mayoritas responden mengalami stres sedang yaitu
sebanyak 70\%. Kesimpulan didapatkan bahwa terdapat hubungan
antara stres dengan proses penyembuhan luka ulkus diabetik.

\section{Abstract}

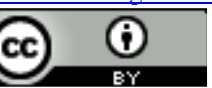




\section{PENDAHULUAN}

Diabetes melitus merupakan suatu kondisi kronis yang terjadi ketika pankreas tidak dapat menghasilkan insulin dalam jumlah cukup atau ketika tubuh tidak dapat menggunakan insulin yang dihasilkan secara efektif. Penyakit diabetes melitus merupakan suatu penyakit yang bersifat universal, dengan kata lain penyakit ini dapat ditemukan di seluruh dunia, termasuk di Negara yang belum berkembang (Smeltzer \& Bare, 2008). Kondisi kronik hiperglikemi pada pasien diabetes berhubungan dengan kerusakan jangka panjang, disfungsi dan kegagalan organ terutama mata, ginjal, saraf, dan pembuluh darah (ADA, 2008).

\section{Berdasarkan data dari World Health} Organitation (WHO) pada tahun 2000 menunjukkan jumlah orang dewasa yang menderita Diabetes melitus di dunia lebih kurang 171 juta orang dan diperkirakan akan meningkat menjadi 300 juta orang pada tahun 2030. Data estimasi International Diabetes Federation (IDF) mendapatkan proyeksi penderita Diabetes melitus pada tahun 2007 untuk wilayah Asia Tenggara 46,5 juta dan pada tahun 2025 diperkirakan akan meningkat menjadi 80,3 juta orang.

Di Indonesia, WHO memprediksi kenaikan jumlah penderita Diabetes melitus yaitu 8,4 juta pada tahun 2000 menjadi sekitar 21,3 juta pada tahun 2030. Indonesia menempati urutan ke-4 terbesar (setelah India, China dan Amerika Serikat) dalam jumlah penderita Diabetes melitus dengan prevalensi $8,6 \%$ dari total penduduk. Laporan hasil Riset Kesehatan Dasar (RISKESDAS) tahun 2007 yang dilakukan pada 24.417 responden berusia diatas 15 tahun menyatakan prevalensi total Diabetes melitus pada penduduk perkotaan Indonesia adalah 5,7\%. Hal ini justru semakin diperberat dengan hasil RISKESDAS pada tahun 2013 yang menyatakan bahwa secara nasional angka prevalensi DM cenderung meningkat sebesar 1,1\% (Badan LitbangkesKemenkes RI, 2013).
Menurut Frykberg et al (2006) salah satu komplikasi pada pasien diabetes adalah neuropati pada ekstremitas bawah yang menyebabkan ulkus diabetik, dan diperkirakan bahwa $15 \%$ pasien dengan diabetes akan mengalami ulkus pada ekstremitas bawah selama perjalanan penyakitnya. Hal ini diperkuat oleh Rowland (2009) yang menyebutkan bahwa penderita diabetes akan mengalami setidaknya satu kali ulkus kaki diabetes selamahidupnya. Ulkus kaki diabetes merupakan penyebab utama $(85 \%)$ dari seluruhamputasi pada ekstremitas bawah (Brookes \& O'Leary, 2006). Data tersebut diperkuat dengan data dari WHO (2012) yang menyebutkan bahwaamputasi tungkai terjadi 10 kali lebih banyak pada diabetes dibandingkan non-diabetes.

Seseorang yang menderita luka akan merasakan adanya ketidak sempurnaan yang pada akhirnya cenderung untuk mengalami gangguan fisik dan psikologis (stress) (Suriadi, 2007). Stress karena ketakutan saat sebelum dilakukannya operasi menyebabkan penurunan inflamasi dan memperpanjang waktu penyembuhan luka dan dapat terinfeksi serta mengalami gangguan penutupan luka. Adanya infeksi pada luka merupakan masalah yang serius bagi pasien, terutama adanya resiko komplikasi pada luka tersebut baik komplikasi lokal maupun sistemik (Marucha \& Suriadi, 2007).

Beberapa teori yang menggambarkan mengapa luka sembuh lebih lama pada pasien yang mengalami stresss karena dapat meningkatkan level beberapa hormon dalam darah, yaitu kortisol, aldosteron, dan epinefrin. Hormonhormon ini dapat memperlambat migrasi komponen sitokin ke daerah luka untuk memulai proses penyembuhan luka (Bowker, 2008; Guo \& DiPietro, 2010; Rowland, 2009). 


\section{METODE PENELITIAN}

Penelitian ini adalah penelitian observasional analitik. Desain penelitian yang digunakan adalah kohort prospektif yang memang sejalan dengan paradigma sebab-akibat (hubungan) dengan melakukan pengamatan secara kontinu dan longitudinal (terhadap proses penyembuhan luka). Penelitian ini dilaksanakan di klinik Ikram Wound Care Center. Jumlah responden dalam penelitian ini sebanyak 30 pasien penderita ulkus diabetik.

\section{HASIL PENELITIAN}

\section{Data Demografi}

1.1. Distribusi Karakteristik Responden Berdasarkan Usia

Tabel 1

Distribusi Responden Berdasarkan Usia Di Klinik Ikram Wound Care Center

\section{Variabel $n$ Mean SD Min Max}

\begin{tabular}{llllll}
\hline Umur & 30 & 56,43 & 11,02 & 30 & 76 \\
\hline
\end{tabular}

Berdasarkan data pada tabel 1 didapatkan distribusi responden berdasarkan umur, rata-rata responden yang ada dilokasi penelitian dengan umur 56 tahun, umur terendah yaitu 30 Tahun dan umur tertinggi adalah 76 Tahun.

\subsection{Distribusi Karakteristik Responden} Berdasarkan Jenis Kelamin

Tabel 2

Distribusi Responden Berdasarkan Jenis Kelamin Pasien Di Klinik Ikram Wound Care Center

\begin{tabular}{ccc}
\hline Jenis Kelamin & $\mathrm{n}$ & $\%$ \\
\hline Laki-Laki & 19 & 63,3 \\
Perempuan & 11 & $36,7 \%$ \\
\hline Total & 30 & 100 \\
\hline
\end{tabular}

Berdasarkan data pada tabel 2 terlihat bahwa dari 30 responden, jenis kelamin responden lebih banyak laki-laki yaitu 19 orang $(63,3 \%)$ dan responden perempuan yaitu 11 orang $(36,7 \%)$.

1.3. Distribusi Karakteristik Responden Berdasarkan Usia

Tabel 3

Distribusi Responden Berdasarkan Lama Menderita Diabetes Mellitus Di Klinik Ikram Wound Care Center

Variabel N Mean SD Min Max

\begin{tabular}{cccccc}
\hline Umur & 30 & 4,97 & 4,6 & 1 & 15 \\
\hline
\end{tabular}

Berdasarkan data pada tabel 3 didapatkan distribusi responden berdasarkan lama menderita diabetes mellitus, rata-rata responden menderita DM selama 5 tahun, terendah menderita 1 tahun dan paling lama yaitu 15 tahun.

\section{Analisis Univariat}

2.1 Distribusi Karakteristik Responden Berdasarkan Jenis Kelamin

Tabel 4

Distribusi Tingkat Stress Responden Di Klinik Ikram Wound Care Center

\begin{tabular}{ccc}
\hline Tingkat Stress & $\mathrm{n}$ & $\%$ \\
\hline Normal & 0 & 0,0 \\
Stress Ringan & 4 & 13,3 \\
Stress Sedang & 21 & 70,0 \\
Stress Berat & 5 & 16,7 \\
\hline Total & 30 & 100 \\
\hline
\end{tabular}

Berdasarkan data pada tabel 4 terlihat bahwa dari 30 responden, paling banyak responden mengalami stress sedang sebanyak 21 (70.0\%), sedangkan stress Berat dan Ringan, masing - masing sebesar 5 (16.7\%) responden dan 4 $(13.3 \%)$ responden. Dari data diatas juga tergambarkan bahwa semua responden penderita ulkus Diabetes mengalami stress. 
2.2 Distribusi Karakteristik Responden

Berdasarkan Jenis Kelamin

Berdasarkan data pada tabel 5 terlihat

Tabel 5

Distribusi Proses Penyembuhan luka pasien

ulkus diabetes Di Klinik Ikram Wound Care

Center

\begin{tabular}{ccc}
\hline $\begin{array}{c}\text { Penyembuhan } \\
\text { Luka }\end{array}$ & $\mathbf{n}$ & \% \\
\hline Baik & 9 & 30,0 \\
Tidak Baik & 21 & 70,0 \\
\hline Total & 30 & 100 \\
\hline
\end{tabular}

bahwa dari 30 responden, paling banyak responden mengalami proses penyembuhan luka yantidak baik sebanyak $21 \quad(70.0 \%)$, sedangkan ressponden yang mengalami proses penyembuhan luka yang baik hanya 9 $(30 \%)$ responden.

\section{Analisis Bivariat}

3.1 Analisis Hubungan Stress Dengan Penyembuhan Luka Ulkus Diabetik

Tabel 6

Analisis Hubungan Stress Dengan Penyembuhan Luka Ulkus Diabetik Di Klinik Ikram Wound Care Center

\begin{tabular}{|c|c|c|c|c|c|c|c|}
\hline \multirow[t]{2}{*}{ Tingkat Stress } & \multicolumn{4}{|c|}{ Penyembuhan Luka } & \multirow[t]{2}{*}{ Total } & \multirow[t]{2}{*}{$\%$} & \multirow[t]{2}{*}{$P$} \\
\hline & Baik & $\%$ & Tidak Baik & $\%$ & & & \\
\hline Stress Ringan & 4 & 13,3 & 0 & $0 \%$ & 4 & $13,3 \%$ & \\
\hline Stress Sedang & 5 & 16,7 & 16 & $53.3 \%$ & 21 & $70.0 \%$ & 0.003 \\
\hline Stress Berat & 0 & 0 & 5 & $16.7 \%$ & 5 & $16.7 \%$ & \\
\hline Total & 14 & 100 & 20 & $100 \%$ & 34 & $100 \%$ & \\
\hline
\end{tabular}

Berdasarkan tabel 6, menunjukkan bahwa responden yang mengalami stress ringan yang proses penyembuhan lukanya baik sebanyak $4(13,3 \%)$ responden. Responden yang mengalami stress sedang dan mengalami proses penyembuhan luka yang baik sebanyak $5(16,7 \%)$ sedangkan yang mengalami proses penyembuhan luka yang tidak baik dan yang paling banyak yaitu $16(53,3 \%)$ responden. Responden yang mengalami stress berat dan tidak baik proses penyembuhan lukanya sebanyak $5(16,7 \%)$ responden. Berdasarkan uji statistic didapatkan hasil Nilai p value 0,001 berarti dibawah <0,05, sehingga disimpulkan bahwa Ada hubungan antara stress dengan proses penyembuhan luka ulkus diabetik.

\section{PEMBAHASAN}

Stres merupakan kombinasi dari psikologis, fisioligis, dan reaksi perilaku sehingga seseorang berespons pada kejadian-kejadian yang mengancam atau menantang mereka. Respon stres juga terdiri dari respon psikologis, fisiologis, dan reaksi perilaku terhadap stresor (Stresless, 2007).

Hasil penelitian ini didapat bahwa responden penderita ulkus diabetik mayoritas mengalami stress sedang. Penelitian ini sejalan dengan penelitian yang menyatakan bahwa distribusi responden yang mengalami gangguan psikologis juga cukup tinggi dimana distribusi tertinggi adalah depresi ringan (21\%), depresi berat (18\%) dan depresi sedang (12\%). Gangguan psikologis pada pasien DM merupakan dampak bahwa seseorang yang terdiagnosa Diabetes Mellitus akan mengalami suatu pola hidup dan adanya bahaya yang mengancam nyawanya (Mufidah, 2018). 
Pasien dengan DM tipe-2 akan lebih rentan mengalami depresi, sehingga kemungkinan angka kejadiannya tinggi. Apalagi pasien DM yang sudah mengalami komplikasi, seperti nefropati ditambah dukungan sosial yang buruk akan menjadi faktor risiko peningkatan depresi (Habtewold et al, 2016).

Hasil penelitian ini juga didapatkan bahwa ada hubungan antara stres dengan proses penyembuhan luka. Dimana pasien yang mengalami stres akan menghambat proses penyembuhan luka. Hal ini sesuai dengan beberapa hasil penelitian yang menyatakan bahwa ada hubungan yang significant antara stress / depresi dengan penyembuhan luka diabetik, setiap penderita yang mengalami luka akan mengalami stress psikologi, stres jangka panjang dapat menunda penyembuhan luka pada luka kronis dengan meningkatkan kadar glukokortikoid dan menyebabkan efek downregulation pada respon inflamasi (Eddine, Itani, Gandoura, \& Ahmed, 2015).

Di penelitian yang lain didapatkan bahwa Stres psikologi pada pasien yang menderita luka secara luas diketahui memiliki hubungan yang signifikant, stres psikologi/ depresi merupakan penyebab paling sering terjadinya luka kronis atau perlambatan penyembuhan luka (Renner \& Erfurt-Berge, 2017). Serta beberapa komplikasi pembedahan seperti penyembuhan yang berkepanjangan dan resiko menimbulkan kecacatan juga menjadi faktor meningkanya stres psikologi yang akan berdampak pula pada lambatnya proses penyembuhan luka (Pinto, Faiz, Davis, Almoudaris, \& Vincent, 2016).

Penderita yang mengalami stres, maka kelenjar adrenal akan menghasilkan kortisol dalam jumlah banyak sehingga dapat menekan sistem Imun. Berlebihnya produksi kortisol juga telah diimplikasikan dengan terjadinya penurunan produksi kolagen, peningkatkan katabolisme dan merangsang produksi katekolamin yang menyebabkan vasokonstriksi pada arteriolarteriol kecil (Morison, 2008). Hasil penelitian yang berhubungan dengan ini adalah bahwa terdapat hubungan antara terjadinya luka dan peningkatan kortisol (Braden, B.J ; Suriadi, 2007).

\section{KESIMPULAN}

Hasil penelitian didapatkan bahwa mayoritas responden mengalami stres sedang. Proses penyembuhan luka pasien juga mayoritas mengalami proses penyembuhan yang lambat. Hasil analisis didapatkan terdapat hubungan antara stress dengan proses penyembuhan luka ulkus diabetik. Dimana penderita yang mengalami stress akan berdampak terhadap proses penyembuhan lukanya yang tidak baik atau lambat.

\section{SARAN}

Berdasarkan hasil penelitian ini, di sarankan untuk perawat dalam melaksanakan tindakan perawatan luka ulkus diabetik untuk dapat mengontrol stress pasien sehingga proses penyembuhannya dapat membaik. Kemudian disarankan untuk penelitian berikutnya untuk memberikan intervensi terkait manajemen stress pasien ulkus diabetik.

\section{REFERENSI}

American Diabetes Association. (2008). Standards of Medical Care in Diabetes. Diabetes Carevol. 31 no. Supplement 1 S12-S54

Bowker J.H. \& Pfeifer M.A. (2008). The Diabetic Foot. Philadelphia: Mosby Elsevier.

Brookes, S \& O'Leary, B. (2006). Feet first: a guide to diabetic foot services. British Journal of Nursing.

Frykberg, R.G, Zgonis, T., Armstrong., D.G., Driver, V.R., Giurini, J.M., Kravitz, S.R., Landsman, A.S., et al. (2006). Diabetic foot disorders a clinical practice guidelines (2006 revision). The journal of foot \& ankle surgery, 45 (5). S1-S66

Guo S. \& DiPietro L.A. (2010). Factors Affecting Wound Healing. J Dent Res; 89(3):219-229. 
Habtewold, T.D., Alemu, S.M., \& Haile, Y.G.(2016). "Sociodemographic, Clinical, and Psychosocial Factors associated with Depression among Type 2 Diabetic out Patients in Black Lion General Specialized Hospital, Addis Ababa, Ethiopia : a cross-sectional Study ". BMC Psychiatry.16 (103) : 1-7

Kementrian Kesehatan Republik Indonesia. (2013). Riset Kesehatan Dasar. Badan Penelitian dan Pengembangan Kesehatan.

Morison, J.M. (2008). Manajemen luka. EGC : Jakarta

Mufidah, S (2018). Gambaran tingkat depresi pada pasien diabetes melitus dengan keluhan penyerta di rsud dr. Moewardi Surakarta.

http://eprints.ums.ac.id/59746/22/naspub .pdf

Rowland, K. (2009). Wound healing perspectives: diabetic foot ulcers. National Healing Coorporation: 6(4).

Smeltzer, S. C., \& Bare, B. G. (2008). Keperawatan Medikal Bedah Brunner \& Suddarth (8th ed.). Jakarta: EGC.

Stressless. Inc. (2007). Stress assessment and personalized program. http://www.stressless.com.

Suriadi. (2007). Manajemen luka. Pontianak: Penerbit STIKEP Muhammadiyah Pontianak.

World Health Organization. (2012). Fact sheet diabetes. http://www/who.int/mediacentre/factshe et. 